\title{
Obituaries.
}

\section{Major B. F. S. Baden-Powell, Honorary Fellow, i860-1937.}

By the death of Major B. F. S. Baden-Powell, at the age of 77 , on October 3 rd, the Society lost its oldest member. Major Baden-Powell was elected a member of the Society at a meeting of the Council held on April 2 Ist, r 88c. Two of the members of Council present were James Glaisher and $\mathrm{P}$. H. Wenham. The membership of the Society at that time was exactly 80 , and included such well known pioneers as James Glaisher, Otto Lilienthal, Thomas Moy, John Stringfellow and P. H. Wenham. With the death of Major Baden-Powell there has been severed a link with a remarkable period of aviation pioneering. 'Гo Major Baden-Powell the Society owed its very existence, for he kept it alive by his enthusiasm and energy during a period when its tiny flame of existence was flickering in the winds of scepticism and opposition.

In 1892 he was elected to the Council and from then onwards delivered many papers before the Society and took part in the discussions of many others. From 1892 to 1896 the membership of the Society steadily dwindled, and at the Council meeting held in November, 1896 , Major Baden-Powell agreed to act as Honorary Secretary. The balance of the Society's assets over its debts was $£ .55$ s. of. The new Honorary Secretary widened the interest in the Society, and the Journal, which had lapsed, was issued quarterly under his editorship. In March, 1897, Major Baden-Powell reported a balance of $\$ 15$ and a membership of 39 , including four honorary members. An extract from the Council Minutes of the time reads: "The Society did not possess sufficient funds to provide a suitable quarterly journal without outside support. However, the Honorary Secretary (Major B. F. S. Baden-Powell) suggested issuing the Journal entirely at his own expense and risk."

In 1899 Major Baden-Powell left England to take part in the South African War, and it was stated in the Council Minutes that, as Honorary Secretary, he had virtually re-established the Society. In July, Igoo, he was elected President of the Society, a post he held for seven years. In 1908 he was elected a VicePresident.

Major Baden-Powell was one of the first to experiment with man-lifting kites, and, as stated in the Journal (April, I897) " the first well authenticated occasion on which a man was raised by a kite was on June $27^{\text {th, }}$ I 894, when Captain Baden-Powell, Scots Guards, conducted some experiments at Pirbright Camp.." Previously he had been a leading spirit in military ballooning. During the Boer War his kites were successfully used for reconnaissance, photography and wireless. It was in I88I he made his first balloon ascent, and in I 884 he owned his own balloon. In 1898 he read his exhaustive paper on Kites in Theory and Practice.

Always a close student of the possibilities of heavier-than-air flight, in March, 1904, he read a paper on Experiments with Aerial Screw Propellers, after having carried out $35^{\circ}$ tests on various types of airscrews. In the Journal for July, 1904, Major Baden-Powell described at length his experiments with gliders at the Crystal Palace, with a view to building a power-driven aeroplane. The experiments were carried out with Mr. J. T. C. Moore-Brabazon.

On October 8th, Igo8, Major Baden-Powell flew with Wilbur Wright, being the second Englishman to fly. The first was Mr. Griffith Brewer, who flew on the same day with Mr. Wilbur Wright, shortly before Major Baden-Powell.

Major Baden-Powell joined the Society before the majority of its present members were born. He not only saved it from extinction, but when he laid down the reins of office after fifteen years of continuous work as a member of Council, Honorary Secretary and President, he saw it well on its way towards the position it now holds as the most authoritative bolly of its kind in the world. 
At the Council meeting held in April, 1930, the following resolution was unanimously passed :-

"The Council in recording in their Minutes that on April 21st, 193\%, Major B. F. S. Baden-Powell, a former President of the Society and for many years a member of Council, had been a member of the Society for fifty years, wish to extend their heartiest good wishes to him for the future, and to congratulate him upon the completion of a record unique in the Society's history."

We are not concerned here with Major Baden-Powell's career outside aviation, only to say that he served on the Nile in 1884 and 1885 , in the South African War 1899-1900, and the Great War 1914-1918. With his death, however, the world has lost one of its most lovable personalities, many have lost a close friend, and the Society has lost a member to whom it must ever owe the deepest debt of gratitude.

\section{Herbert Charles William Brewer, Associate Fellow, r904-1937.}

Herbert Charles William Brewer was killed at the early age of 33 in a railway accident at Swanley Junction on June 27 th. The son of the late Rev. H. P. Brewer, he was educated at Lancing College, and Queen's College, Cambridge, where he took an honours degree in engineering. In 1927 he joined the technical staff of the Fairey Aviation Company and showed outstanding ability. He was responsible for a great deal of the design of the Battle, and became an authority on stressed skin construction. Later, at Stockport, he became chief technical officer on the production of the Battle. He took every opportunity of flying on flying trials to obtain a practical insight of the machine with which he had been concerned.

A man who was personally immensely popular and able, the death of $\mathrm{H}$. C. W. Brewer is a serious loss of one who would have risen high in his profession. He was elected an Associate Fellow of the Society in I935.

\section{Reginald Joseph Mitcheld, Fellow, r895-1937.}

The death of Reginald Joseph Mitchell on June IIth, 1937, meant to British aviation the loss of one of its most brilliant designers.

Born at Stoke-on-Trent, he served his apprenticeship with Kerr, Stuart and Co., Ltd., of which he became assistant engineer. In 1916 he joined the Supermarine Aviation Works, Ltd., and became chief engineer and designer in Igro. In 1922 he helped to modify the A.D. flying boat which won the Schneider Trophy for Great Britain, and was concerned in the designs of an amphibian for the Martlesham competition, machines for various foreign governments and the Air Ministry.

In 1924 came Mitchell's first outstanding success with the S.4 which made a world's speed record of 226.76 miles per hour. In 1927 he produced the $S .5$ which won the Schneider Trophy at Venice, and in 1929 the S.6 which won the trophy at Southampton, and in 193i the S.6b which finally won the trophy outright for Great Britain, achievements without parallel in aircraft design. The S.6b made a speed record of $407 \frac{1}{2}$ m.p.h. following the last Schneider Trophy race, and for his work Mr. Mitchell was made a C.B.E.

Despite the intense concentration during those years necessary to produce the fastest seaplanes in the world, Mr. Mitchell was able to design the flying boats Southampton, Scapa and Stranraer, which have been widely ordered by the Royal Air Force. He also designed the Seagull for coastal patrol for the Royal Australian Air Force and the Walrus amphibian for the Fleet Air Arm. A year before his death he produced the Spitfire, one of the fastest single-seater fighters in the service. 